\title{
Hepar Histology of Mice (Mus musculus L) Indicated by Pre-Diabetes Mellitus Type 2 (Pre- Type 2 DM) After Red Rice Yeast Treatment
}

\author{
Rudiana Agustini \\ Department of Chemistry \\ Surabaya State University \\ Surabaya, Indonesia \\ rudianaagustini@unesa.ac.id
}

\author{
Erlix Rakhmad Purnomo \\ Department of Biology \\ Surabaya State University \\ Surabaya, Indonesia \\ erlixpurnama@unesa.ac.id
}

\author{
Agus Widodo \\ Department of Mathematics \\ Brawijaya University \\ Malang, Indonesia \\ prof.agus_widodo@yahoo.com
}

\begin{abstract}
The hepar is an organ that has a complex and vital role, which can be damaged. Hepar damage can be seen from the condition of the cells. His study aimed to provide a histological description of mice hepar (Mus musculus L.) that was indicated by pre-type 2 DM (pre-type 2 DM) after the treatment of red rice yeast was carried out. The study was conducted on male mice weighing 20-24 grams and indicated pre-Type 2 DM. the mice were grouped into six groups based on the test material given, namely: red rice, red rice yeast, Yeast hydrolysate enzymatic (YHE) - red rice, positive control (glibenclamide + CMC-Na), normal control (commercial feed + CMC) -Na), and negative control (pre type 2 DM + CMC-Na). Each group was treated with $1 \mathrm{ml}$ of the test material by oral gavage, then histology of the liver was observed to determine the level of liver cell damage. Based on liver histology results of mice, it was found that the level of cell damage was indicated by the level of hepatocyte damage resulting from the treatment of red rice yeast, YHE red rice, glibenclamide + CMC Na, commercial feed + CMC Na, and pre-type $2 \mathrm{DM}+\mathrm{CMC} \mathrm{Na}$ respectively -according to $12,29,47,18$, and $53 \%$. Red rice yeast has the best ability to regenerate liver cells among the treatments given. This result can be seen from the smallest level of red rice yeast hematocyte damage, which is $12 \%$ and the largest is negative control $(53 \%)$, namely mice with type 2 DM and given CMC Na feed.
\end{abstract}

Keywords-hepar histology, Mus Muculus L, pre-type 2 DM, red rice yeast treatment

\section{INTRODUCTION}

The hepar is one of the vital organs that functions as a center for metabolism and excretion of waste metabolites. Hepar tissue is composed of two types of hepar cells, namely parenchyma cells, and nonparenchym cells. Parenchym cells occupy about $70-85 \%$ of liver volume. The hepar parenchyma cells are known as hepatocytes, in the form of one or two nucleated polyhedrates [1]. This cell is constantly undergoing mitosis, therefore it can experience regulation if there is damage.

The hepar has a vital function, including producing bile. The function of bile is to hydrolyze fat. The constituent components of bile are bile salts, cholesterol, bilirubin, electrolytes, and water [2]. Bilirubin is the result of hemoglobin degradation, then this bilirubin will be absorbed and metabolized by the hepar. The result of hemoglobin degradation will also produce iron which is stored in the hepar and bones to form new blood cells [3]. The hepar produces an important compound for blood clotting, including vitamin $\mathrm{K}$, whose formation process is influenced by the availability of bile [4]. The hepar also plays a role in fat metabolism, namely energy metabolism in the hepar[5]. The liver functions as a storage place for carbohydrate metabolism, which is glycogen and the compound will be released back into glucose when the body's cells need energy [6]. Hepar as a place for storing vitamins and minerals. Some vitamins include: vitamins $\mathrm{A}, \mathrm{D}, \mathrm{E}$, and B12 are mostly stored in the liver [7], also stores iron from the breakdown of hemoglobin in the form of ferritin. Hepar also stores copper, a place of protein metabolism. The hepar as a place for the degradation of amino acids and urea synthesis, the formation of plasma proteins and interconversion between different amino acids [8]. The hepar also filters blood from all over the body. The hepar filters and removes compounds from the body [9], including hormones, such as estrogen, aldosterone, and compounds from outside the body, including alcohol and other drugs. Immunological functions [10]. The hepar is part of the mononuclear phagocyte system. It contains high numbers of cells that are involved in immune activity. These cells destroy any disease-causing agent that might enter the hepar through the gut. Hepar is also the production of albumin [11]. Albumin is the most common protein in blood serum. It transports fatty acids and steroid hormones to help maintain correct pressure and prevent the leaking of blood vessels. The hepar synthesizes angiotensinogen [12]. This hormone raises blood pressure by narrow blood vessels when alerted by the production of an enzyme called renin in the kidneys.

In the hepar can experience fatal consequences, including the presence of fat vacuoles that accumulate in the hepar cells. Such conditions result in the hepar not functioning properly. This disorder is known as fatty liver disease which usually occurs together with obesity. At a threshold level, more than 5 to 10 percent of the hepar weight is fat. If the body produces too much fat, or if the fat is not properly metabolized, it can build up in the hepar. If more fat than this builds up in the hepar, this is known as hepar disease.

Fat hepar disease is often related to obesity, high blood pressure, diabetes mellitus (DM), and high cholesterol. DM is known to have 2 types, namely type 1 and type 2 diabetes mellitus. Type $2 \mathrm{DM}$ is a chronic metabolic disorder caused by the body unable to use effectively produced insulin, a hormone that regulates blood glucose levels. Normal blood 
glucose is $100-126 \mathrm{mg} / \mathrm{dL}$, prediabetes $>126<150 \mathrm{mg} / \mathrm{dL}$ Patients with type 2 diabetes are characterized by blood glucose levels $\geqslant 150 \mathrm{mg} / \mathrm{dL}$. The results of the study using mice showed that the treatment with the administration of red rice yeast intake and YHE (Yeast Hydrolysate Enzymatic) in mice can reduce blood glucose levels. The decrease in blood glucose levels of mice treated with red rice yeast was $161 \mathrm{mg}$ / dL and YHE was $131 \mathrm{mg} / \mathrm{dL}$. Red rice yeast is yeast grown in red rice, while YHE is a yeast extract from the results of enzymatic hydrolysis. Damaged hepar cells can be regenerated. The only internal organ of mammals capable of natural regeneration of lost tissue is the hepar; $25 \%$ of the hepar can regenerate into a whole heart [13]. Hepar regeneration. as growth compensation in mammals[14]. This tissue can regenerate completely with at least $25 \%$ of the tissue still present. Research conducted on mice that removed two-thirds of hepar tissue was still able to regenerate again within 5-7 days. In humans, because it has a larger and more complex size, the regeneration process requires a longer time. The process of hepar tissue regeneration requires several compounds. The results showed that red rice yeast of red rice contains good biochemical components for cell regeneration, namely protein, chromium, and anthocyanin. One of the hepar damage can be seen microscopically from hepatocytes or parenchymal cells that experience atrophy (cell wasting), necrosis, necrobiosis, fatty, or apoptosis. Necrosis leads to cell or tissue death, is irreversible, especially regarding the cell nucleus and some are natural (= necrobiosis). Therefore looking at the hepar histology is very important to determine the level of cell damage. Base on the background his study aimed to provide a histological description of mice hepar (Mus musculus L.) that was indicated by pre-type $2 \mathrm{DM}$ (pre-type $2 \mathrm{DM}$ ) after the treatment of red rice yeast was carried out.

\section{EASE OF USE}

The study aimed to describe the hepar histology of mice that was carried out in several stages, including the preparation of test materials, obesity induction, treatment using the test material, and hepar histology of mice.

\section{A. Preparation of Test Material}

Red rice yeast was the yeast that is grown in a medium of red rice flour. In the initial stage, rice was milled and sieved with a size of 100 mesh sieve, then each rice flour was added with distilled water with a ratio of $5: 1(\mathrm{~b} / \mathrm{v})$. The mixture is heated to boiling and finally, a gel (gelatinization process) will be formed. The gel was allowed to cool then hydrolyzed using the enzyme $\alpha$-amylase and glucoamylase for 6 hours, room temperature $(28 \pm 5 \mathrm{oC})$. Hydrolyzate was ready to be used as a yeast growth medium. The yeast used was commercial yeast bakery. Yeast was put into hydrolyzate with a ratio of 5: $1(\mathrm{v} / \mathrm{w})$, then fermented for 10 days. The fermentation results were then centrifuged at a speed of 6000 rpm for 15 minutes and yeast residues will be obtained which were ready for further processing. In the study use YHE red rice (yeast hydrolysate enzymatic) to compare that it's made by enzymatical hydrolysis. Yeast was hydrolyzed using bromelain. Hydrolysis in this study was carried out at $37^{\circ} \mathrm{C}$ for 24 hours. The hydrolyzate obtained was YHE which was ready to be used as a test material.

\section{B. Induction of Obesity}

The initial stage is an adaptation, mice were placed in the cage according to the treatment to be given, then adapted for seven days and fed during adaptation to commercial feed and given drinks were replaced every day. Mice were weighed one by one using a digital scale and then measured their blood glucose levels using a nesco multi check. Obesity induction was done by giving fat and fructose feed. Animal fat was given daily at $0.4 \mathrm{~mL}$, fructose was given at $0.6 \mathrm{~mL}$ and commercial feed every day for approximately 1 week, then the next stepwas measuring blood glucose levels and weight.

\section{The Treatment of Mice Use Test Material}

The test material in this study was yeast red rice and yeast which have been enzymatically hydrolyzed (YHE). Positive, negative and normal controls are used as a comparison. Table 1 shows the formulation of the test material used in this study.

TABLE I. FORMULATION OF TEST MATERIAL

\begin{tabular}{|c|l|}
\hline Material Test & \multicolumn{1}{|c|}{ Formulation } \\
\hline Red rice Yeast & $\begin{array}{l}\text { Giving red rice yeast } 1 \mathrm{~mL} / \mathrm{per} \\
\text { day }\end{array}$ \\
\hline Red rice YHE & $\begin{array}{l}\text { Giving YHE red rice } 1 \mathrm{~mL} / \mathrm{per} \\
\text { day }\end{array}$ \\
\hline $\begin{array}{c}\text { Glibenclamide (Positive } \\
\text { Control) }\end{array}$ & $\begin{array}{l}\text { Control glibenclamide, made } \\
\text { diabetes and given glibenclamide } \\
(0.9 \mathrm{mg} / 200 \text { g bb mice) in CMC- } \\
\text { Na 0.2\% }\end{array}$ \\
\hline Diabetic Control & $\begin{array}{l}\text { Control of diabetes (negative } \\
\text { control), made diabetes and only } \\
\text { given 0.2\% CMC-Na }\end{array}$ \\
\hline Normal Control & $\begin{array}{l}\text { Normal control, non-diabetes, was } \\
\text { given } 0.2 \% \text { CMC-Na }\end{array}$ \\
\hline
\end{tabular}

The administration of the test material was carried out on male mice (Mus musculus L.) DDW strains aged six weeks weighing 25-30 grams by using gavage needles as much as $1 \mathrm{~mL} /$ mice / day for 1 week.

\section{Surgery and Observation of Hepar Histology}

Mice that were treated for one week were dissected and the hepar was washed in a physiological solution, put into Bouin's solution and made histological preparations. Hepar tissue observed in this study was left lobe slice. Preparation using the paraffin method, then staining using hematoxylin and eosin. Observation of hepar tissue histology using a light microscope with a magnification of $100 \mathrm{X}$ and $400 \mathrm{X}$, with five different sub-fields of view. Every sub-view counts the total number of hepar cells and damaged day cells (apoptosis and necrosis). Then calculated the percentage of damage that occurs using the following formula. Data were analyzed descriptively quantitatively.

$$
\text { Damage }(\%)=\frac{\text { number of damaged cells }}{\text { number of normal cells }}
$$

\section{RESULTS AND DISCUSSION}

The results of observations using a light microscope carried out on the hepar of mice by treating yeast and YHE red rice and positive, negative and normal control groups after 1 week found normal hepatocytes and hepatocytes to 
change the form of parenchymatic degeneration, hydropic degeneration (apoptosis) and necrosis. Hepatocytes are cells that have a round nucleus with a clear membrane and it has a polyhedral shape. Changes in function and structure due to chemical compounds or due to abnormalities that lead to liver tissue damage can be characterized by biochemical lesions such as inflammation, fibrosis, cell degeneration, or necrosis. This change can be observed using a microscope. Necrosis is the death of cells or tissue in living organisms. The nucleus of the dead cell looks smaller, chromatin and reticular fibers multiply. The nucleus becomes denser and then the cell becomes eosinophilic (cariolisis). The mice hepar tissue is shown in Fig. 1.

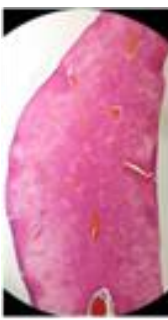

Restict yeus

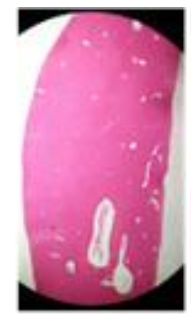

Bedrisente

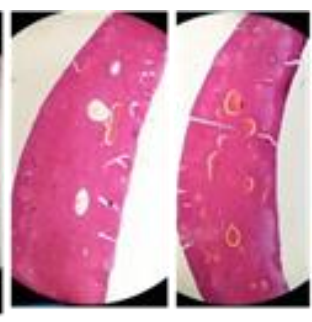

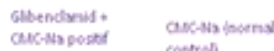
cenchas

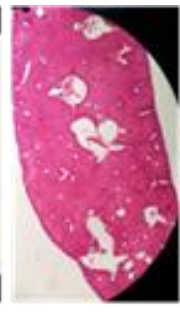

Neguz conteol
Fig. 1. The hepar mice using light microscope with light microscope magnification of $100 \mathrm{X}$

Fig. 1 shows that the biggest hepar tissue damage occurs in negative control is $\mathrm{DM}$ with $\mathrm{CMC} \mathrm{Na}$ treatment. Treatment with red rice yeast and red rice YHE showed little tissue damage compared to other treatments. The best treatment is giving red rice yeast.

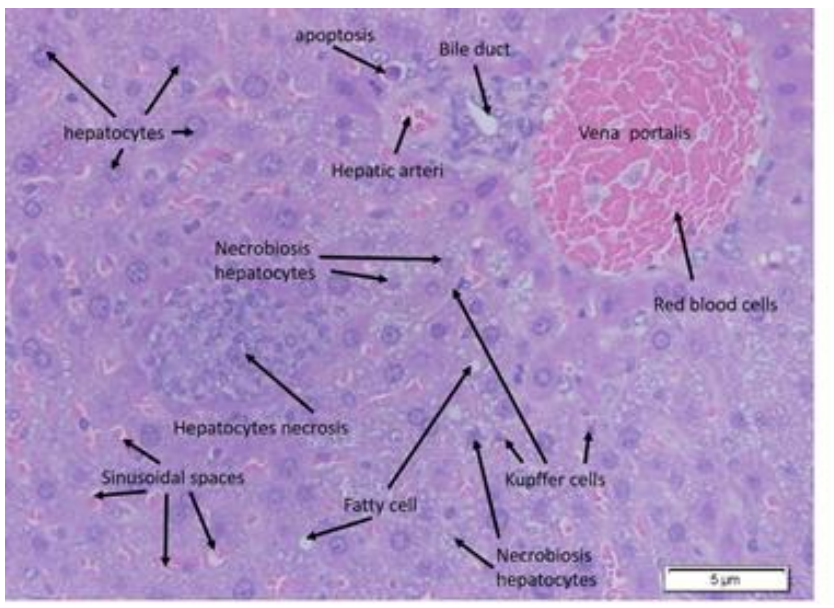

Fig. 2. Histology of mice hepar with the treatment of red yeast rice and its parts at one point of view (light microscope, magnification 400X)

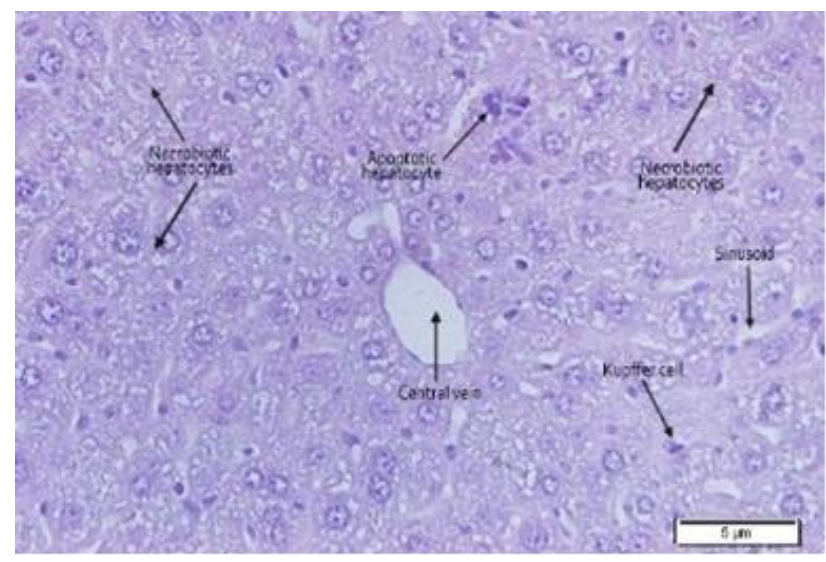

Fig. 3. Histology of mice hepar with the treatment of red rice-YHE and its parts at one point of view (light microscope, magnification 400X)

The hepar is the most frequently damaged organ[15], because the metabolism of various compounds or drugs mainly occurs in the hepar, so the possibility of damage to these organs becomes very large[16]. If the metabolic process does not run normally, it will cause various diseases, one of which is a disease that occurs in the hepar. The cells contained in the hepar will be deposited so that they will experience changes. Consumption of certain drugs or dietary foods can cause hepar damage in a short time or after several weeks or maybe several months. Hepar tissue damage can be in the form of hepatocyte necrosis, cholestasis, or the onset of hepar dysfunction slowly. The hepar histology of mice, parts, and damage to hepatocyte cells in various treatments are shown in Fig. 2-6.

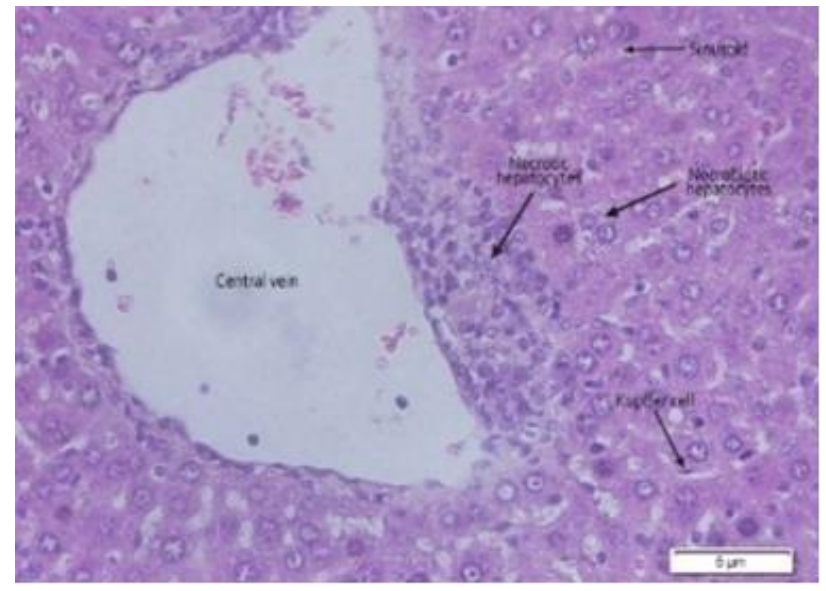

Fig. 4. Histology of mice hepar with the treatment of glibenclamide + CMC-Na (positive control) and its parts at one point of view (light microscope, magnification 400X) 


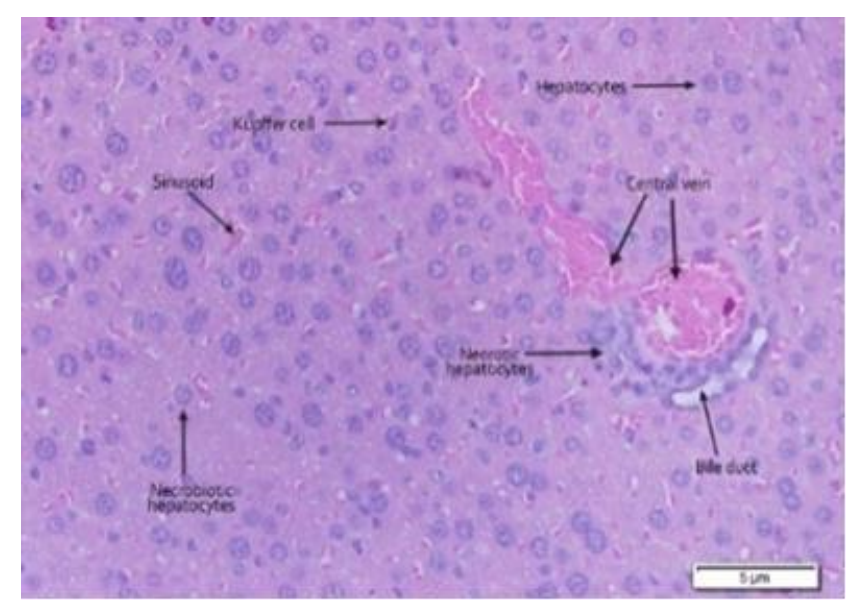

Fig. 5. Histology of mice hepar with the treatment of normal control and its parts at one point of view (light microscope, magnification 400X)

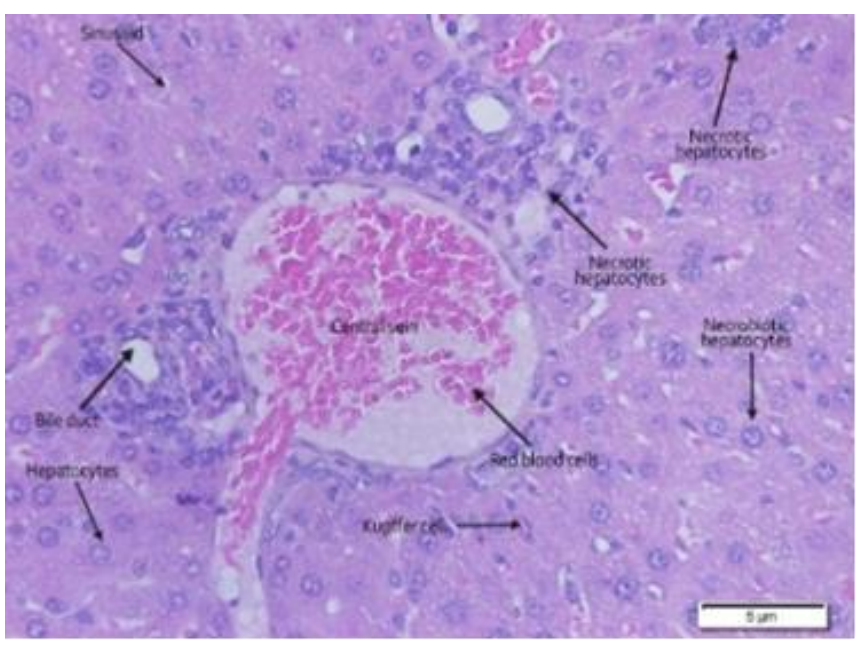

Fig. 6. Histology of mice hepar with the treatment of DM+CMC-Na (negative control) and its parts at one point of view (light microscope, magnification $400 \mathrm{X}$ ).

The conditions of hepatocyte cells in mice in various treatments as shown in Table 2 .

TABLE II. FORMULATION OF TEST MATERIAL

\begin{tabular}{|l|c|c|c|c|c|c|c|c|c|c|}
\hline \multirow{2}{*}{ Treatment } & \multicolumn{2}{|c|}{$\begin{array}{c}\text { Field of } \\
\text { View 1 }\end{array}$} & \multicolumn{2}{c|}{$\begin{array}{c}\text { Field of } \\
\text { View 2 }\end{array}$} & \multicolumn{2}{c|}{$\begin{array}{c}\text { Field of } \\
\text { View3 }\end{array}$} & \multicolumn{2}{c|}{$\begin{array}{c}\text { Field of } \\
\text { View4 }\end{array}$} & \multicolumn{2}{|c|}{$\begin{array}{c}\text { Field of } \\
\text { View5 }\end{array}$} \\
\cline { 2 - 11 } & $N$ & $R$ & $N$ & $R$ & $N$ & $R$ & $N$ & $R$ & $N$ & $R$ \\
\hline $\begin{array}{l}\text { Red rice } \\
\text { Yeast }\end{array}$ & 107 & 7 & 101 & 11 & 112 & 21 & 126 & 16 & 103 & 20 \\
\hline $\begin{array}{l}\text { Red rice } \\
\text { YHE }\end{array}$ & 79 & 44 & 87 & 44 & 56 & 28 & 199 & 75 & 233 & 73 \\
\hline $\begin{array}{l}\text { Positive } \\
\text { Control }\end{array}$ & 82 & 114 & 78 & 172 & 118 & 50 & 113 & 60 & 120 & 61 \\
\hline $\begin{array}{l}\text { Normal } \\
\text { Control }\end{array}$ & 191 & 117 & 216 & 29 & 202 & 22 & 209 & 39 & 176 & 17 \\
\hline $\begin{array}{l}\text { Negative } \\
\text { Control }\end{array}$ & 99 & 126 & 104 & 146 & 90 & 145 & 127 & 89 & 120 & 109 \\
\hline
\end{tabular}

The level of hepatocyte damage as an illustration of the liver condition of mice in various treatments as shown in Table 3.
TABLE III. LEVELS OF MICE HEPATOCYTE DAMAGE

\begin{tabular}{|l|c|c|c|c|}
\hline \multirow{2}{*}{ Treatment } & \multicolumn{2}{|c|}{ Total Cell } & Total cells & $\begin{array}{c}\text { Damage } \\
\text { observed } \\
\text { Level } \\
(\%)\end{array}$ \\
\hline $\begin{array}{l}\text { Red rice } \\
\text { Yeast }\end{array}$ & 549 & 75 & 624 & 12 \\
\hline $\begin{array}{l}\text { Red rice } \\
\text { YHE }\end{array}$ & 654 & 264 & 918 & 29 \\
\hline $\begin{array}{l}\text { Positive } \\
\text { Control }\end{array}$ & 511 & 457 & 968 & 47 \\
\hline $\begin{array}{l}\text { Normal } \\
\text { Control }\end{array}$ & 994 & 224 & 1218 & 18 \\
\hline $\begin{array}{l}\text { Negative } \\
\text { Control }\end{array}$ & 540 & 615 & 1155 & 53 \\
\hline
\end{tabular}

Table 3 shows that the smallest level of hematocyte damage is red rice yeast which is equal to $12 \%$ and the largest is negative control (53\%), namely mice with type 2 $\mathrm{DM}$ and given CMC Na feed. CMC Na is used as a source of mouse fiber. YHE red rice shows a higher level of damage compared to red rice yeast. YHE is the result of enzymatic hydrolysis of red rice yeast which has a higher amount of dissolved amino acid components compared to yeast. This compound is more easily metabolized than protein, but in the process of making YHE is centrifuged during removal of water, so that many anthocyanins and other chemical compounds are suspected of being wasted. Therefore, it is recommended that when making YHE using freeze dryer instead of the centrifuge to get YHE residue. Thus the chemical components present in red rice yeast are thought to have the potential to regenerate hepar cells. Anthocyanins are known compounds that play a role in cell regeneration. Red rice yeast also shows lower levels of hepatocyte damage in hepar cells when compared with treatment with DM drugs (glibenclamide + CMC Na). Glibenclamide is a drug commonly used by sufferer DM and can reduce blood glucose levels. Red rice yeast also showed a smaller level of hematocyte damage (12\%) when compared to normal controls $(18 \%)$. Red rice yeast is yeast grown in red rice, while YHE is a yeast extract from the results of enzymatic hydrolysis. Normal control is mice treated with commercial feed plus CMC Na. In type $2 \mathrm{DM}$ and hepar disease, insulin resistance plays a major role in central pathology. Therefore an understanding of the glucose homeostatic defense is essential for the development of therapies in diabetes and hepar disease. Mammalia hepar is the only organ that can regenerate. Damage or loss of tissue by $25 \%$ can be regenerated to produce a complete network [13]. Hepar regeneration. as growth compensation in mammals and although it is an organ whose cells undergo slow regeneration, they have the amazing regenerative ability [14].

\section{CONCLUSION}

Based on the histological results of the hepar, we can know the level of hepatocyte damage, respectively red rice, red rice YHE, glibenclamide + CMC Na, commercial feed + CMC Na, and CMC Na + DM are 12, 29, 47, 18 and 53\%. Red rice yeast has the best ability to regenerate liver cells compared to other treatments. This result can be seen from the smallest level of red rice yeast damage, which is $12 \%$, while the damage level of type $2+\mathrm{CMC}-\mathrm{Na} \mathrm{DM}$ as a negative control is $53 \%$, therefore it is recommended that red rice yeast can be used as an anti pre- type $2 \mathrm{DM}$. 


\section{REFERENCES}

[1] G. Pocock, Human Physiology 3rd Ed, Inggris: Oxford University Press, 2006.

[2] M. Hundt, H. Basit and S. John, Physiology, Bile Secretion, StatPearls, 2019

[3] L. O'Brien, P. Hosick, K. John, D. Stec and T. Hinds, "Biliverdin reductase isozymes in metabolism," Trends Endocrinol Metab, vol. 26, no. 4, pp. 212-220, 2015.

[4] L. Amitrano, M. Guardascione, V. Brancaccio and A. Balzano, "2002," Coagolation Disorders in Liver Disease Semin Liver Dis, vol. 22, no. 1, pp. 83-96, 2002.

[5] L. Rui, "Compr Physiol," vol. 4, no. 1, pp. 177-197, 2014.

[6] D. Raddatz and G. Ramadori, "Carbohydrate metabolism and the liver : actual aspects from physiology and disease," vol. 45, no. 1 , pp. 51-62, 2007.

[7] J. C. Ozougwu, "Physiology of the Liver," International Journal of Research in Pharmacy and Bioscience, vol. 4, no. 8, 2017.

[8] Campbell, "Liver: metabolic functions.," Anaesthesia \& Intensive Care Medicine. , vol. 7, no. 2, pp. 51-54, 2006.
[9] M. Hoffman, "Picture of Liver," WEBMD LLC, 2014

[10] B. D.P., B. Gao and G. Gershwin, "2013," vol. 3, no. 2, pp. 567-598, Compr Physiol.

[11] J. L. Throop, M. E. Kerl and 2. C. V. 2. N. 1. Leah A. Cohn, "Compedium," vol. 26, no. 12, 2004.

[12] M. J, B. J, C. E, R. JP and C. P., "Biochemistry and regulation of angiotensinogen," Clin Exp Hypertens A, vol. 5, no. 7-8, pp. 10051019, 1983.

[13] H. Dieter, Liver Regeneration. as compensatory growth in mammals, 2011.

[14] D. Gruyter, Robbins and Cotran Pathologic Basis of Disease (7th ed), Berlin, 1999

[15] L. F. C., Basic Toxicology. Second Edition., Jakarta: Indonesia University Press., 1994.

[16] L. W. Powell and D. W. Piper, Basic Gastroenterology of Hepatology, Jakarta: PT. Pharos, 1989. 